\title{
The growth and rooting dimensions of the Local and Solomon Albizia in the agroforestry system
}

\author{
NIKMATUL AZIZAH ${ }^{1, \nu}$, NURHENI WIJAYANTO ${ }^{2, v \vee, ~ D E S T A ~ W I R N A S ~}{ }^{3, v \vee v, ~}$ \\ ${ }^{1}$ Program of Tropical Silviculture, School of Graduates, Institut Pertanian Bogor. Jl. Lingkar Kampus IPB Darmaga, Bogor 16680, West Java, Indonesia. \\ Tel./fax. +62-251-8622642, `email: nikmatul_azizah@apps.ipb.ac.id \\ ${ }^{2}$ Department of Silviculture, Faculty of Forestry, Institut Pertanian Bogor. J1. Ulin, Kampus IPB Darmaga, Bogor 16680, West Java, Indonesia. \\ Tel.: +62-251-8621677, Fax.: +62-251-8621256, ${ }^{\vee *}$ email: nurheniw@ gmail.com \\ ${ }^{3}$ Department of Agronomy and Horticulture, Faculty of Agriculture, Institut Pertanian Bogor. Jl. Meranti, Kampus IPB Darmaga, Bogor 16680, West \\ Java, Indonesia. Tel.: +62-251-8629354, Fax.: +62-251-8629352, "rvemail: dwirnas@ gmail.com
}

Manuscript received: 1 August 2019. Revision accepted: 23 September 2019.

\begin{abstract}
Azizah N, Wijayanto N, Wirnas D. 2019. The growth and rooting dimensions of the Local and Solomon Albizia in the agroforestry system. Biodiversitas 20: 3018-3023. Albizia (Falcataria moluccana (Miq.) Barneby \& J.W.Grimes) is one of the leguminous plants that has a fast-growing character and profitable wood. Some types of albizia such as local albizia and Solomon albizia are cultivated by the community. Albizia planting can be integrated with crops such as upland paddy in agroforestry systems. Research on albizia planted in the agroforestry system was conducted to analyze the growth and root dimensions. This research was conducted for six months at the Cikabayan Field, Faculty of Forestry, IPB University, Bogor, West Java. This study was composed of two activities, those : (i) analyzing the effect of the albizia provenance on the growth of diameter, height, and canopy area, (ii) analyzing the root dimensions in agroforestry systems. The results showed that the albizia provenance had significant effect fo diameter, height, canopy area, and root length variable. F1 Solomon albizia has the best growth in all measured variables. F1 Solomon albizia has differed significantly with F2 Solomon and local albizia.
\end{abstract}

Keywords: Agroforestry, albizia, canopy, growth, root

\section{INTRODUCTION}

Agroforestry (AF) is an integrated agriculture approach between trees and shrubs or crops to get the higher productivity, better economic value, and sustainable landuse system (Umrani and Jain 2010; Kaur et al. 2017). Sustainable land-use concept in AF means as productive agriculture enterprise which maintenance environment quality. The system is economic, social, and ecology valueoriented (Novita et al. 2012; Glover et al. 2013). Tumpangsari is one of the AF types that capable to produce higher productivity and economic value than slash-andburn agriculture. Furthermore, plant combination in AF is soil conservation form through land fertility improvement and erosion prevention.

The AF system aims to maintain ecological balance by combining forest stands and agricultural crops. One of the suitable and acceptable tree species developed under AF system is Legume family. Legumes are well known to have the ability binding atmospheric nitrogen (Biswas and Gresshoff 2014). Its ability can help improve soil fertility (Iskandar et al. 2017). Among those of Legume family, albizia is one of the species that already known well within communities. Planting albizia can increase the content of organic matter, and nitrogen content in the soil (Nugroho et al. 2018).

According to Hughes et al. (2011), albizia is a fastgrowing species. The wood of albizia can be harvested within 4-10 years depending on several purposes and objectives. Albizia was characterized to have a light canopy, and this can be optimized by planting food crops under its stand (Senjaya 2018). Albizia is also known to have high economic value of timber because it is widely used by the pulp and paper industry (Siregar et al. 2006), raw materials for furniture, and matches industry. Along with the economic value of the albizia timber, the leaves can also be used for animal feed. In Sukabumi, West Java, albizia can be planted in several agroecosystem types such as yards, fields/huma, tegal, and kebon kai (Iskandar et al. 2017).

Various provenances of albizia have been cultivated by people in Indonesia, such as Solomon, Wamena, and local albizia. Solomon albizia is the albizia from the Solomon Islands, located in the Pacific Ocean, while local albizia is the albizia was cultivated by communities from their local location. Various albizia types that were cultivated by many locations called provenance. This Solomon provenance has different growth rates and disease resistance. Growth is one of the parameters that can be measured to determine the productivity of a plant. Several studies about albizia in AF system have already been conducted in growth and disease resistant aspect. However, research on the growth of local albizia and Solomon albizia on AF land is still limited. The characters of roots among woody plants are important to determine the root morphology and the regulatory actions for root pruning.

Considering the importance of growth rate and root dimension in albizia, the study will determine the growth 
and root dimensions of albizia in AF system. Albizia provenance with the best growth performance and root dimension is highly recommended to be chosen and planted in the AF system.

\section{MATERIALS AND METHODS}

\section{Study area}

This research was conducted for six months from August 2018 to February 2019. The experimental plot is located in Cikabayan Forest, Faculty of Forestry, IPB University, Bogor, West Java, Indonesia (Figure 1). The plot size is $762 \mathrm{~m}^{2}$ with $0 \%$ of slope and at an altitude of 162 meters above sea level (m asl). Study site has the annual temperature at $28{ }^{\circ} \mathrm{C}$, humidity of $70 \%$, and sunlight intensity ranges between 1924 to 23059 lux in frequent measurement. Light intensity was measured in the morning, afternoon, and evening in three days for a week, and then the data were averaged (Hartoyo et al. 2015). During the observation period, mean annual rainfall ranges between $20.5 \mathrm{~mm}$ to $428 \mathrm{~mm} / \mathrm{month}$ (BMKG 2018). $\mathrm{pH}$ at study location was 5.48, C-org by $2.05 \%$, N-total of $0.18 \%$, and cation exchange capacity of $15.99 \mathrm{cmol} / \mathrm{kg}$.

According to Krisnawati et al. (2011), albizia plants can grow optimally with conditions of $22-29^{\circ} \mathrm{C}$ with a minimum rainfall of $291 \mathrm{~mm} / \mathrm{month}$. The need for macro and micronutrients is also needed by albizia. Therefore the basic fertilizer was given in the form of manure from cattle so that nutrients needs were fulfilled. According to Setiadi et al. (2014), local albizia and Solomon albizia can grow from coastal forests to areas with an altitude of 1600 masl and can grow optimally at an altitude of 0-1000 masl.

\section{Procedures}

Local and Solomon albizia seeds were taken from community forests in Kendal, Central Java. This research used local albizia, F2 Solomon albizia, and F1 Solomon albizia seeds. Seeds were immersed in water for 24 hours before sowed. Sprouting was happened at three days after planted. One month after sprouted, seedlings were transferred into polybag with the dimension of $12 \times 17 \mathrm{~cm}$. At the age of one month (average seedling height $28.99 \mathrm{~cm}$, the seedlings were planted in the field.

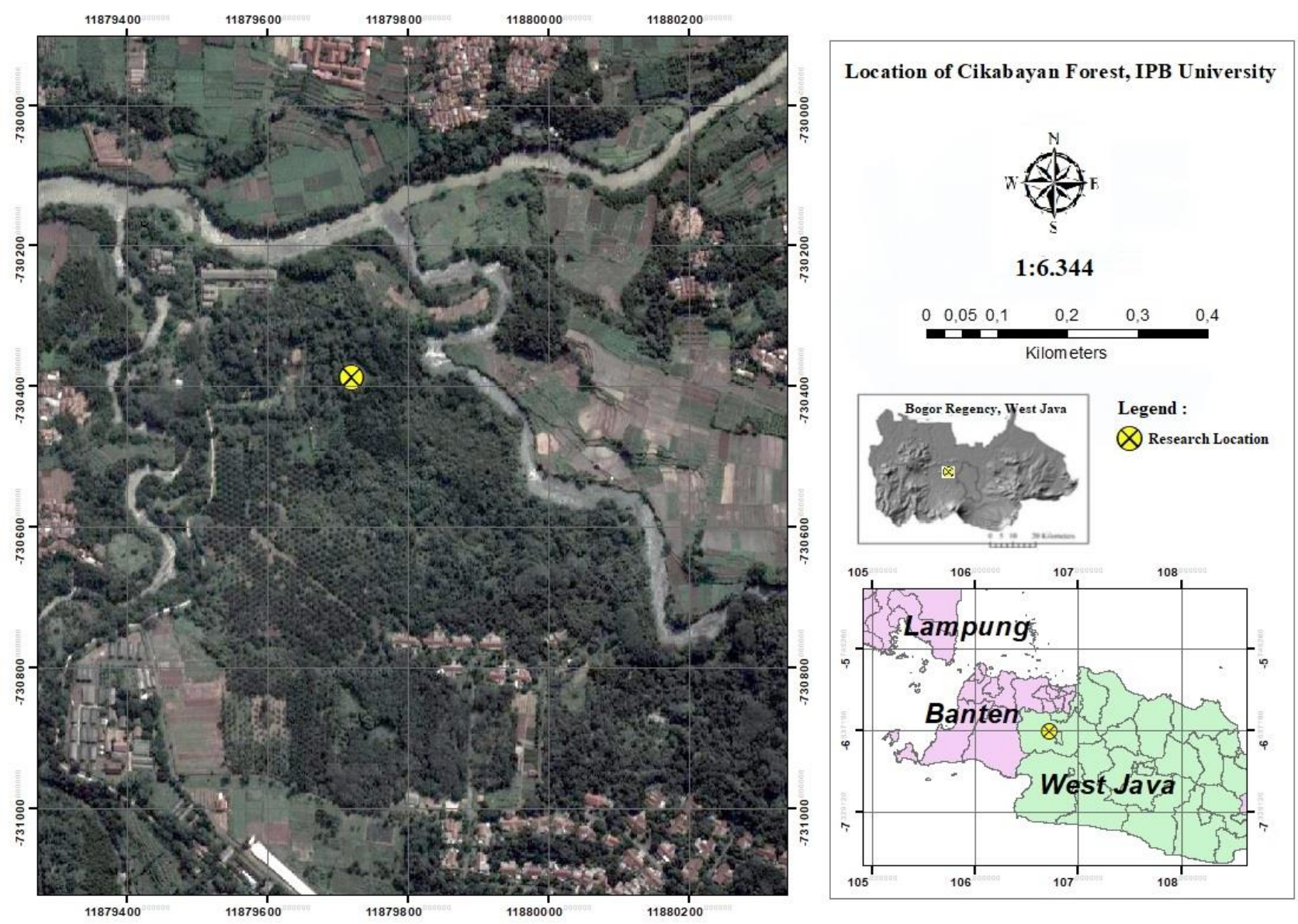

Figure 1. Research location of Cikabayan Forest with coordinates $06^{\circ} 32^{\prime} 48.8^{\prime}$ 'S $06^{\circ} 43^{\prime} 02.4^{\prime \prime}$ 'E. 
Land preparation was conducted by land clearing and soil extraction. $30 \mathrm{~cm}$-depth planting hole was prepared with the spacing distance of $1.5 \mathrm{~m} \times 1.5 \mathrm{~m}$. This spacing distance recommended for realizing potential of genetically improved planting stock (Nicodemus 2014). This experiment used manure from cow dung and organic fertilizer. Maintenance of albizia stands such as pruning branches were conducted every month to maintain the light intensity reaching the ground floor. In this $\mathrm{AF}$ scheme, albizia were intercropped with paddy rice. Weeding was carried out two weeks after planting and was frequently done considering its condition in the planting plot. To prevent insect attract, we used two types of pesticides those were : $3 \%$ active carbofuran to eradicate termites and 25 $\mathrm{gL}^{-1}$ deltamethrin to eradicate leaf caterpillars.

Variables observation included growth in stem diameter, height, canopy area, root diameter, root length, and root depth. Measurements of stem diameter, plant height, and canopy area were conducted every two months for six months, while measurements of variables root diameter, root length, and root depth were conducted at the beginning of planting and at the age of six months after planting. Measurement of stem diameter and root diameter was carried out using a caliper tool.

Data were collected on three treatments for albizia provenances with eight replications. One replication composed of three albizia plants totaling 72 albizia seedlings for observation. Stem diameter was measured at one $\mathrm{cm}$ above the ground. Seedlings heights were measured from the base of the stem that borders the surface of the ground to the end of the young stem growth point. The canopy area was measured on the four longest sides of the canopy which are perpendicular to each other, then averaged to find the crown radius. Measurement on the root dimensions was done on the lateral roots that grow horizontally. The diameter of the root was measured at three root points then averaged. The root length was measured from the neck of the root to the tip of the root, while the root depth was measured from the ground to the neck of the root.

\section{Data analysis}

Data were analyzed using analysis of variance (ANOVA) to determine the effect of albizia provenance in this study. If the ANOVA results at the 5\% level respectively have a significant effect on the observed variables, then the Duncan's Multiple Range Test (DMRT) is continued at the 5\% level respectively to find out albizia provenance has a significant effect. Processing data using SAS version 9.0 software.

\section{RESULTS AND DISCUSSION}

\section{The Growth of Local and Solomon Albizia}

Variables measured in the growth of local and Solomon albizia including stem diameter, plant height, and canopy area. The results of ANOVA of the effect albizia provenance can be seen in Table 1.
Diameter is the one and only variable that has a significant effect at $5 \%$ respectively on each measurement. Diameter is the growth that more influenced by environment factor, while height is more influenced by genetic factor. DMRT results of the influence albizia provenance on diameter variable were presented in Table 2 and influence the albizia provenance on plant height and canopy area were presented in Table 3.

F1 Solomon Albizia is the greater diameter growth in monthly measurement. F1 Solomon albizia was differed significantly with F2 Solomon and local albizia, while F2 Solomon and local albizia has not differed significantly in monthly measurement.

Table 1. ANOVA mean square of the effect on the albizia provenance

\begin{tabular}{lccc}
\hline \multirow{2}{*}{ Measurement } & \multicolumn{3}{c}{ Observation variable } \\
\cline { 2 - 4 } & Diameter & Height & Canopy area \\
\hline $2^{\text {nd }}$ map & $0.40 *$ & $751.31 \mathrm{~ns}$ & $01660259.75 \mathrm{~ns}$ \\
$4^{\text {th }}$ map & $1.96 *$ & $2864.88 *$ & $64209635.70 *$ \\
$6^{\text {th }}$ map & $2.53 *$ & $4267.55 \mathrm{~ns}$ & $47891438.00 \mathrm{~ns}$ \\
\hline
\end{tabular}

Note: The numbers in the table are significant values. *= treatment has a significant effect at the 5\% level respectively with a significant value $(\operatorname{Pr}<F) 0.05(\alpha)$, ns= treatment does not have a significant effect at the 5\% level respectively with a significant value $(\operatorname{Pr}>F) 0.05(\alpha)$. map= month after planting

Table 2. Mean and DMRT results on diameter variable in local and Solomon albizia

\begin{tabular}{clc}
\hline Measurement & Albizia provenance & Diameter $(\mathbf{c m})$ \\
\hline $2^{\text {nd }}$-map & Local albizia & $0.61 \mathrm{~b}$ \\
& F1 Solomon albizia & $1.00 \mathrm{a}$ \\
& F2 Solomon albizia & $0.62 \mathrm{~b}$ \\
$4^{\text {th }}$-map & Local albizia & $2.36 \mathrm{~b}$ \\
& F1 Solomon albizia & $3.18 \mathrm{a}$ \\
& F2 Solomon albizia & $2.30 \mathrm{~b}$ \\
$6^{\text {th }}$-map & Local albizia & $3.28 \mathrm{~b}$ \\
& F1 Solomon albizia & $4.31 \mathrm{a}$ \\
& F2 Solomon albizia & $3.40 \mathrm{~b}$ \\
\hline
\end{tabular}

Note: Numbers followed by different letters in the same column show variables that are significantly different according to the DMRT at the $5 \%$ level respectively.

Table 3. Mean and DMRT results on height and canopy area variables in local and Solomon albizia

\begin{tabular}{llll}
\hline $\begin{array}{l}\text { Measure- } \\
\text { ment }\end{array}$ & Albizia provenance & $\begin{array}{c}\text { Height } \\
(\mathbf{c m})\end{array}$ & $\begin{array}{c}\text { Canopy area } \\
\left(\mathbf{c m}^{2}\right)\end{array}$ \\
\hline $2^{\text {nd }}$-map & Local albizia & 90.03 & 4471.16 \\
& F1 Solomon albizia & 107.69 & 4581.44 \\
& F2 Solomon albizia & 91.95 & 5309.57 \\
$4^{\text {th }}$-map & Local albizia & $261.23 \mathrm{~b}$ & $11787.23 \mathrm{~b}$ \\
& F1 Solomon albizia & $297.98 \mathrm{a}$ & $17188.23 \mathrm{a}$ \\
& F2 Solomon albizia & $271.77 \mathrm{ab}$ & $13004.32 \mathrm{~b}$ \\
$6^{\text {th }}$-map & Local albizia & 408.28 & 20255.08 \\
& F1 Solomon albizia & 454.44 & 24795.13 \\
& F2 Solomon albizia & 432.68 & 24106.32 \\
\hline
\end{tabular}

Note: Numbers followed by different letters in the same column show variables that are significantly different according to the DMRT at the 5\% level respectively. 

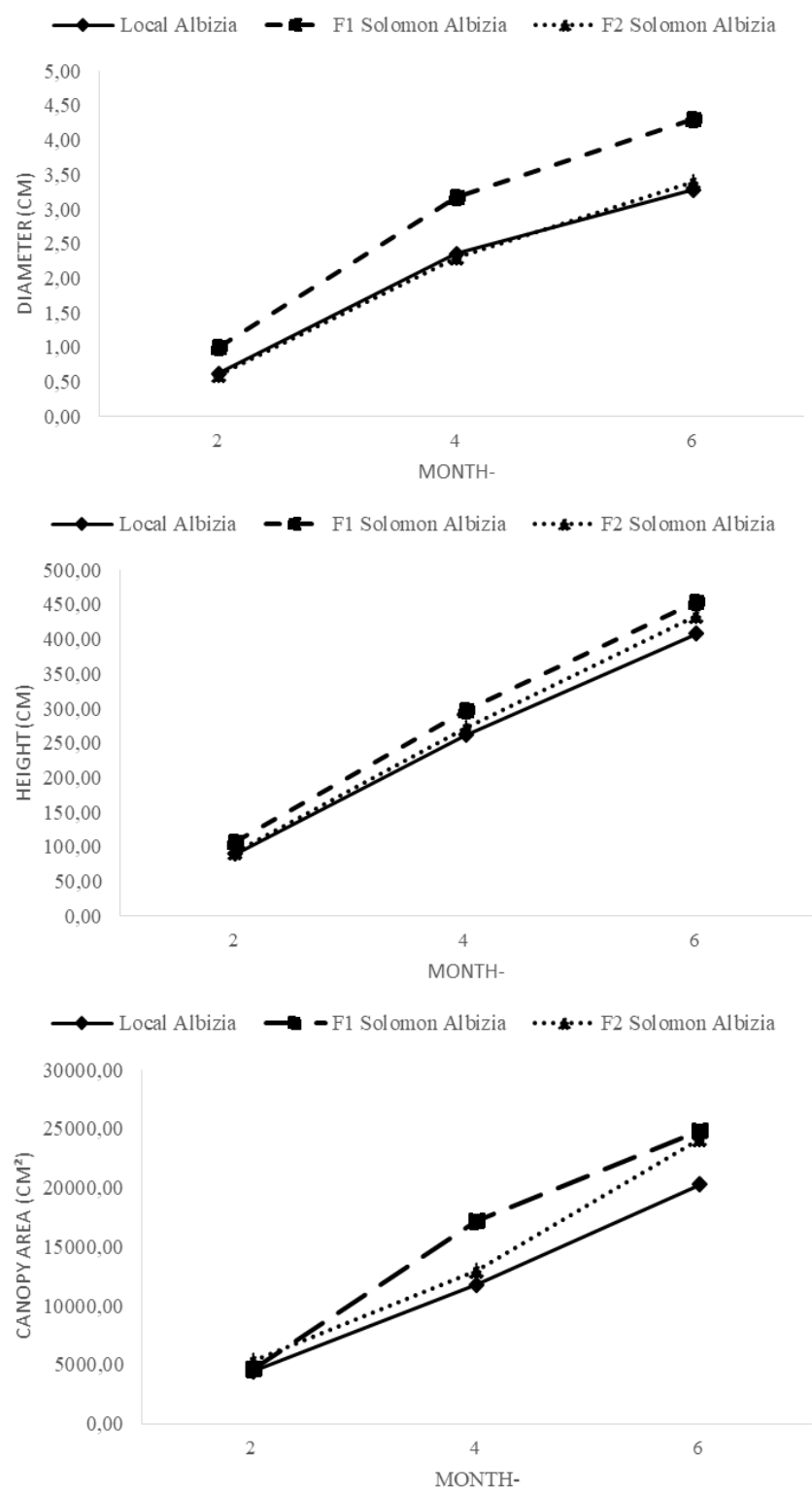

Figure 2. Local and Solomon albizia growth graph

The mean growth of height and canopy area albizia (Table 3) shows that F1 Solomon albizia has differed significantly with local albizia and F2 Solomon albizia just in $4^{\text {th }}$-month measurement. The growth graph of albizia is shown in Figure 2.

The diameter, height, and canopy area graph shows that as a plant grows, the size of a plant also increases. Solomon albizia has better growth than local albizia in $6^{\text {th }}$ measurement in all variables. F1 Solomon albizia showed the best growth for all variables and monthly measurement.

\section{Dimensions of Local Albizia and Solomon Albizia}

Observation variables on root dimensions include root diameter, root length, and root depth, as presented in Table 4.
Table 4. ANOVA mean square results in albizia root dimensions

\begin{tabular}{lccc}
\hline \multirow{2}{*}{ Treatment } & \multicolumn{4}{c}{ Observation variables } \\
\cline { 2 - 4 } & Root diameter & Root length & Root depth \\
\hline Albizia provenance & $0.01 \mathrm{~ns}$ & $10313.96 *$ & $3.50 \mathrm{~ns}$ \\
\hline Note: The numbers & in the table are significant values. * \\
treatment has a significant effect at the $5 \%$ level respectively with \\
significant value $(\operatorname{Pr}<\mathrm{F}) 0.05(\alpha), \mathrm{ns}=$ treatment does not have a \\
significant effect at the $5 \%$ level respectively with significant \\
value (Pr> F) $0.05(\alpha)$.
\end{tabular}

Table 5. Mean and DMRT results on root diameter, root length, and root depth variables in local and Solomon albizia

\begin{tabular}{lccc}
\hline Albizia provenance & $\begin{array}{c}\text { Root diameter } \\
\text { (cm) }\end{array}$ & $\begin{array}{c}\text { Root length } \\
\text { (cm) }\end{array}$ & $\begin{array}{c}\text { Root depth } \\
\text { (cm) }\end{array}$ \\
\hline Local albizia & 0.43 & $118.84 \mathrm{a}$ & 16.51 \\
F1 Solomon albizia & 0.51 & $119.62 \mathrm{a}$ & 15.19 \\
F2 Solomon albizia & 0.44 & $057.04 \mathrm{~b}$ & 15.94 \\
\hline
\end{tabular}

Note: Numbers followed by different letters in the same column show variables that are significantly different according to the DMRT at the 5\% level respectively.

The roots measured in this study were those root branches produced by the primary root and lateral root. Based on Table 4, root length is the only variable that has significantly different based on the ANOVA result. Furthermore, DMRT test was conducted to determine what provenance that differed from other in root length variable (Table 5). Table 5 shows that local albizia has the bigger diameter root and the deeper root depth, and then F1 Solomon albizia has the highest root length.

\section{Discussion}

Growth is a development in the form of increasing the size of an organic system. Planting of trees at the same time is expected to have a uniform growth so the purposes of management can be reached. The growth parameters of albizia seedlings can be used as an illustration of the genetic quality of seeds, although some plants at young age do not yet to express the differences in phenotypic performance (Rohandi et al. 2014). Based on Table 1, the ANOVA results indicated that the diameter was a variable that has a significant effect at the 5\% level significance on each measurement. Diameter growth is classified as secondary growth due to the influence of cambium activity, while the height and canopy area are classified as primary growths that are affected by meristem tissue (Hoffman and Tomescu 2013; Spirko and Rossi 2015). The diameter of the plant will continue to grow along with the development of the plant. Increasing the value of a plant's diameter affects the increment and productivity of trees during harvesting (Hapsari et al. 2018).

Solomon albizia in this study has a better diameter than local albizia were affected by genetic factor. Differences in genes found in an individual will affect adaptability through changes during the development period. Table 2 shows that the mean diameter of Solomon albizia is higher than local albizia. This can be caused by the possibility that 
the Solomon albizia stand has a relatively low genetic diversity than local albizia, so they have the same adaptive ability (Setiadi et al. 2014). The growth differences between F1 Solomon and F2 Solomon albizia caused by the possibility that cross-pollination of albizia. F1 Solomon albizia has a better diameter growth than F2 Solomon albizia, because of cross-pollination can change the genetic pool. The same results of Hardiyanto (2010), showed that Solomon albizia produced better growth compared to local albizia from Temanggung. In Temanggung, two years old local albizia's diameter is $12 \mathrm{~cm}$ comparing than two years old Solomon albiza's diameter is $16 \mathrm{~cm}$. In another study, according to Setiadi et al. (2014) showed that 12 months old Solomon albizia's diameter is $5.7 \mathrm{~cm}$, and local albizia's diameter is $9 \mathrm{~cm}$.

Although the variables of plant height showed an effect just at $4^{\text {th }}$ months after planting, the F1 Solomon albizia was able to produce the highest plant height, i.e. with a mean of $297.98 \mathrm{~cm}$. F1 Solomon albizia is likely more adaptable to habitat environmental factors such as light intensity, temperature, and humidity as Senjaya (2018) stated that these factors may influence plant growth including plant physiology. The height of a plant is very sensitive an influenced by light intensity and height plant occurs because of elongation the number of cells (Dewi et al. 2017; Gardner et al. 2008) and strongly influenced by meristem tissue in the areas of the ends of plants that are very sensitive to the presence of sunlight. However, based on Figure 2, the height of the albizia plant had a nonsignificant average growth in each treatment. This is presumably due to plant maintenance activities in the form of pruning. Trimming shoots and twigs can affect the overall growth rate as a whole.

The canopy size of a plant can describe inter-plant competition, it related to space competition. Space competition may relate directly to competition in getting light that will be able to influence the canopy, canopy area, and canopy density. Heavy or infrequent canopy growth can affect growth due to responses from growing conditions, competition, or disease disorders (Raharjo and Sadono 2008). According to Suci and Heddy (2018), the level of light intensity affects the canopy width of puring plant Codiaeum variegetum. The lower light intensity, the higher canopy width will be formed. This is supported by Raharjo and Sadono (2008) that the existence of shade results in a broader size and shape of leaves to increase the ability in capturing light so that canopy would also grow wider and faster.

Based on Table 1, local and Solomon albizia had different value on canopy area at fourth months after planting. This was suggested due to intensive pruning activities conducted on albizia stands to maintain light penetration for upland rice plants cultivation. The higher density of albizia canopy along with increasing age of albizia will affect upland rice yields (Senjaya 2018).

Roots are parts of plants that usually grow through the soil. Root has an important role in absorbing water and nutrients so photosynthesis and other metabolic processes can take place. Based on Table 4, all observation variables did not provide significantly different effects based on the
DMRT except the root length. Differences in root diameter are thought due to barriers to the spread and penetration of roots in the soil. Root dispersion barriers can be affected by treatment at the beginning of planting. Furthermore, genetic factor that affected root diameter is the amount of vascular tissues. Equivalent xylem vessel diameter often correlates to the root diameter (Shioutsu et al. 2015).

According to Suryanto et al. (2005), root development is closely related to canopy growth. The lengthen of root length, effecting the bigger of canopy growth. This is because the dense tree canopy will reduce the light reaching the ground surface and will affect the plants below it (Dewi et al. 2018; Rahmawathi et al. 2017). Sabarnudin et al. (2004) also stated that crown density in AF affected canopy density in that area. Based on the root length data obtained, these results were not positively correlated with the canopy area data obtained. This is different from the (Dewi et al. 2018) stated. F1 Solomon albizia has the longest root length than other albizia followed by local albizia then F2 Solomon albizia. But, canopy area variable in $6^{\text {th }}$ measurement showed that $\mathrm{F} 1$ Solomon albizia has the bigger canopy area than other albizia, followed by F2 Solomon albizia then local albizia. The longer the roots and the greater number of roots, the higher the plant height and canopy area. This condition is closely related to the amount of nutrients and water that can be absorbed by plant roots, as well as the symbiosis between the roots of albizia and the bacteria Rhizobium which can increase nutrient uptake in the soil (Sari and Prayudyaningsih 2018). Previous study showed that the root length affected by nitrogen and phosphorus fertilizer (Razaq et al. 2017). Nitrogen and phosphorous fertilizers were given to upland paddy that planted under the albizia stand. Root length is related to plant resistance when there is a lack of water. When plants experience lack of water, the roots will look for soil layers that have sufficient water availability. According to Reubens et al. (2011), taproot growth is more dominant than lateral root growth until the age of four months in Jatropha curcas.

Root development is the key to achieve high yield (Tomasi 2016; Martinez et al. 2018). Root depth is related to the quantity of water absorption and nutrients. Previous study showed that the deeper and longer root is the more able to absorb water and nutrients. A greater rooting depth can increase access to subsoil water and interception mobile nutrient such as nitrate (Nichols et al. 2016; Grieu et al. 2001; Dunbabin et al. 2003). Root depth in this experiment has not differed in albizia provenance and same reported was stated Baldi and Toselli 2013). The development of roots is also closely related to soil fertility.

\section{ACKNOWLEDGEMENTS}

This study is one of the topics of the Academic Grant of Prof. Nurheni Wijayanto, funded by Ristekdikti, Indonesia. Therefore, on this occasion, we would like to thank the IPB University, Indonesia that already permitted the research location at Cikabayan Forest. We also conveyed gratitude to the field assistant, Adnani, who has assisted collect the 
tools and materials necessary and kindly helped used to provide information.

\section{REFERENCES}

Badli E, Toselli M. 2013. Root growth and survivorship in cow manure and compost amended soil. Plant Soil Environ 59 (5): 221-226.

Biswas B, Gresshoff PM. 2013. The role of symbiotic nitrogen fixation in sustainable production of biofuels. Intl J Mol Sci 15: 7380-7397.

BMKG [Badan Meteorologi Klimatologi dan Geofisika]. 2018. Laporan iklim harian. [internet]. https: //www.dataonline.bmkg.go.id [Indonesian]

Dewi N, Wijayanto N, Gusmaini. 2017. Dimensions growth of Azadirachta excelsa and Phyllanthus spp. in agroforestry system. Biodiversitas 18 (2): 494-499.

Dewi N, Wijayanto N, Gusmaini. 2018. Dimensi dan sistem perakaran sentang (Azadirachta excelsa Jack.) dalam sistem agroforestri dengan meniran (Phyllanthus sp.). Jurnal Silvikultur Tropika 9 (2): 116-119. [Indonesian]

Dunbabin V, Diggle A, Rengel Z. 2003. Is there an optimal root architecture for nitrate capture in leaching environments? Plant. Cell and Environment 26: 835-844.

Gardner FP, Pearce RB, Mitchell RL. 1985. Physiology of Crop Plants. Iowa State University Press, United States.

Glover EK, Ahmed AB, Glover MK. 2013. Analysis of socio-economic conditions influencing adaption of agroforestry practices. Intl J Agric For 3 (4): 178-184.

Grieu P, Lucero DW, Ardiani R, Ehleringer JR. 2001. The mean depth of soil water uptake by two temperate grassland species over time subjected to mild soil water deficit and competitive association. Plant Soil 230: 197-209.

Hardiyanto EB. 2010. Factors that Influence the Productivity and Quality of Sengon Wood. Faculty of Forestry, UGM, Yogyakarta. [Indonesian]

Hartoyo APP, Wijayanto N, Budi SW. 2015. Agroforestry Innovation Supports the Independence of the Nation. In: Rachman E Kusumawardhana D, Widyaningsih TS, Kuswantoro DP (eds): Proceeding of the 2015 National Agroforestry Seminar. Balai Agroforestry Research and Development of Technology, Bandung, 19 November 2015. [Indonesian]

Hartoyo APP, Wijayanto N, Budi SW. 2015. Agroforestry Innovation Supports the Independence of the Nation. In: Rachman E, Kusumawardhana D, Widyaningsih TS, Kuswantoro DP (eds); Proceeding of the 2015 National Agroforestry Seminar. Balai Agroforestry Research and Development of Technology, Bandung, 19 November 2015. [Indonesian]

Hoffman LA, Tomescu AMF. 2013. An early origin of secondary growth: Franhueberia gerriennei gen. Am J bot 100 (4): 754-763.

Hughes RF, Johnson MT, Uowolo A. 2011. The invasive alien tree: Falcataria moluccana: its impacts and management. XIII International Symposium on Biological Control of Weeds, Hawaii, USA, 11-16 September 2011.

Iskandar J, Iskandar BS, Partasasmita R. 2017. Introduction of Paraserianthes falcataria in the traditional agroforestry 'huma' in Karangwangi Village, Cianjur, West Java, Indonesia. Biodiversitas 18 (1): 295-303

Kaur R, Sharma M, Puri S. 2017. Impact of tree management on the growth and production behavior of Zea mays under an agroforestry system in Solan District of Himachal Pradesh. Imperial J Interdisciplin Res 3 (2): 502-510.

Krisnawati H, Varis E, Kallio M, Kanninen. 2011. Paraserianthes falcataria (L.) Nielsen Ecology, Silviculture and Productivity. Center for International Forestry Research, Bogor.
Martinez MM, Ortega R, Janssens M, Fincheira P. 2018. Use of organic amendements in table grape: effect on plant root system and soil quality indicators. J Soil Sci Plant Nutr 18 (1): 100-112.

Nichols SN, Hoffman RW, Williams WM, Koten CV. 2016. Rooting depth and root depth distribution of Trifolium repens $x$ T. uniflorum interspecific hybrids. Ann Bot 118: 699-710.

Nicodemus A. 2014. Cultivation Techniques for Casuarina. In: Buvaneswaran C, Sivakumar V, Prasanth RS, Kumar K (eds) Transfer of Tree Cultivation Technologies. Insti tute of Forest Genetics and Tree Breeding, Coimbatore.

Novita E, Suryaningrat, Andriani I, Widyotomo S. 2012. Analysis of sustainable economic sector of coffee plantation in Sidomulyo Village, Jember District. Jurnal Teknologi Pertanian Agritech 32 (2): 126-135. [Indonesian]

Nugroho AW, Widuri SA, Sayektiningsih T. 2018. Earthworm population at the post coal mining field in East Kalimantan Indonesia. Indonesia J For Res 5 (2): 81-93.

Raharjo JT, Sadono R. 2008. Model tajuk jati (Tectona grandis L.F.) dari berbagai famili pada uji keturunan umur 9 tahun. Jurnal Ilmu Kehutanan 2 (2): 89-95. [Indonesian]

Rahmawathi AM, Wijayanto N, Wulandari AS. 20017. Growth analysis of sentang (Azadirachta excelsa) in agroforestry system. Biodiversitas 18 (2): 589-592.

Razaq M, Zhang P, Shen HI, Salahuddin. 2017. Influence of nitrogen and phosphorous on the growth and root morphology of Acer mono. PLoS ONE 12 (2): e0171321. DOI: 10.1371/journal.pone.0171321.

Rohandi A, Gunawan, Pieter LAG. 2014. Variation seed physiology quality and growth sengon seedlings from some Papua's provenances. Jurnal Penelitian Hutan Tanaman 11 (1): 11-20. [Indonesian]

Ruebens B, Achten WMJ, Maesetal WH. 2011. More than biofuel Jatropha curcas root system symmetry and potential for soil erosion control. J. Arid Environ 75 (2): 201-205.

Sabarnudin MS. Suryant P, Aryono WB. 2004. Mahony (Swietenia macrophylla King) trees dynamics in alley cropping agroforestry. Ilmu Pertanian 11: 63-73.

Senjaya N, Wijayanto N, Wirnas D, Achmad. 2018. Evaluasi sistem agroforestri sengon dengan padi gogo terhadap serangan cendawan

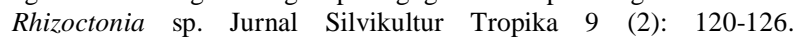
[Indonesian]

Setiadi D, Baskorowati L, Susanto M. 2014. Pertumbuhan sengon solomon dan responnya terhadap penyakit karat tumor di Bondowoso, Jawa Timur. Jurnal Pemuliaan Tanaman Hutan 8 (2): 121-136. [Indonesian]

Shiotsu F, Abe J, Doi T, Gau M, Morita S. 2015. Root morphology and anatomy of field-grown Erianthus arundinaceus. Am J Plant Sci 6: 103-112.

Siregar UJ, Rachmi A, Massijaya MY, Ishibashi N, Ando K. Economic analysis of sengon (Paraserianthes falcataria) community forest plantation, a fast-growing species in East Java, Indonesia. For Policy Econ 9: 822-829.

Spirko LS, Rossi AM. 2015. Manner of apical meristem destruction affects growth, reproduction, and survival of sea oxeye daisy. J Bot 2015: 1-11.

Suci CW, Heddy S. 2018. Pengaruh intensitas cahaya terhadap keragaan tanaman puring (Codiaeum varigetum). Jurnal Produksi Tanaman 6 (1): 161-169. [Indonesian]

Suryanto P, Tohari, Sabarnurdin MS. 2005. Dinamika sistem berbagai sumberdaya (resouces sharing) dalam agroforestri: dasar pertimbangan penyusun strategi silvikultur. Ilmu Pertanian 12 (2): 165-178. [Indonesian]

Umrani R, Jain CK. 2010. Agroforestry Systems and Practices. Mehra Offset Press, Delhi. 